\title{
BEST PRACTICE: IMPLEMENTASI PROGRAM PENDIDIKAN KEWIRAUSAHAAN MELALUI PENERAPAN PROSES PEMBELAJARAN DALAM MEWUJUDKAN KREATIVITAS DAN INOVASI PESERTA DIDIK SMA NEGERI 2 PEKANBARU TAHUN 2017
}

(Implementation of Entrepreneurship Education Program through the Implementation of the Learning Process in Realizing Creativity and Innovation of Participants in SMA Negeri 2 Pekanbaru Academic Year 2017)

Oleh: Zurina*)

*) Kepala Sekolah SMA Negeri 2 Pekanbaru

\begin{abstract}
The purpose of this article was to find out whether Entrepreneurship Education Program may create an active creativity and inovation of students at SMA Negeri 2 Pekanbaru. The Entrepreneurship Education Program is one of the answers to overcome various problems, especially the problem of unemployment in Indonesia. Students need to be given debriefing on entrepreneurial competencies with the aim of preparing students in order to create jobs, alleviate the problem of unemployment, poverty, economic downturn and politically can lift the dignity and dignity as an independent nation. With the development of entrepreneurship programs the writer as the principal is more proactive in finding and utilizing opportunities to achieve success so that it will bring change in the organization towards a more adaptive one in the face of various environmental changes and 21 st century challenges.
\end{abstract}

Kata Kunci: Implementation, Entrepreneurship Education Program, Realizing Creativity and Innovation

\section{PENDAHULUAN}

SMA Negeri 2 Pekanbaru sebagai salah satu sekolah yang mendapatkan kepercayaan dari pemerintah dalam mengimplementasikan program kewira usahaan di kota Pekanbaru khususnya dan Provinsi Riau pada umumnya. Program kewirausahaan dikembangkan tidak hanya untuk menghasilkan manusia yang terampil intelektual saja tetapi yang inspiratif dan pragmatis. Pengembangan pendidikan kewirausahaan harus dilaksanakan secara terprogram, sistematis melalui kurikulum dan pembelajaran. Untuk mengokohkan focus pada pembelajaran maka Kepala sekolah harus mampu bekerja sama dalam menentukan visi dan tujuan sekolah dan mengimplementasikannya secara bersama dengan seluruh anggota organisasi dan mengacu kepada standar yang telah ditentukan. Hal ini dimaksudkan agar tingkat ketercapaian suatu tujuan dapat diketahui dengan tepat sebagai bahan evaluasi kinerja organisasi sekolah secara bersama.

Berkenaan dengan hal di atas Direktorat Pembinaan SMA pada tahun anggaran 2016 telah menberikan pembinaan dalam bentuk asistensi dan singkronisasi program Kewirausahaan di SMA Negeri 2 Pekanbaru, serta memberikan bantuan pemerintah untuk penguatan dan peningkatan mutu SMA tentang Kewirausahaan. Penguatan pembelajaran Kewirausahaan (entrepreneurship) merupakan salah satu jawaban untuk mengatasi berbagai masalah yang ada terutama masalah pengangguran di Indonesia. Peserta Didik 
perlu diberi pembekalan tentang kompetensi kewirausahaan dengan tujuan untuk mempersiapkan peserta didik dalam rangka menciptakan lapangan kerja, mengentaskan masalah pengangguran, kemiskinan, keterpurukan ekonomi dan secara politis dapat mengangkat harkat dan martabat sebagai bangsa yang mandiri.

Guru sebagai pemegang kunci utama dalam mendorong pertumbuhan para peserta didik agar memiliki jiwa kewirausahaan dalam berinovasi dan mampu menyikapi kebutuhan, keinginan dan harapan masyarakat akan jasa pendidikan sebagai penentu keberhasilan sekolah.Untuk mewujudkan sekolah yang mandiri dan kreatif serta berupaya memajukan, mengembangkan dan memandirikan sekolah tidak terlepas dari pengelolaan pendidikan yang lebih menekankan kepada kemandirian dan kreativitas sekolah yang mempunyai kompetensi kewirausahaan yang tinggi. Sikap inovatif membutuhkan suatu pemikiran yang lebih dari biasa sehingga akan mudah menggapai tujuan dan dapat menunjukan eksestensinya dalam bersaing di era globalisasi

Program kewirausahaan dikembangkan di SMA Negeri 2 Pekanbaru tidak hanya untuk menghasilkan peserta didik yang terampil secara intelektual saja tetapi peserta didik yang inspiratif dan pragmatis melalui pengembangan pendidikan kewirausahaan yang dilaksanakan secara terprogram, sistematis melalui kurikulum dan pembelajaran. Program kewirausahaan yang dirancang dan disusun di SMA Negeri 2 Pekanbaru pada awal tahun Pelajaran dan dicantumkan pada kalender akademik yang telah disepakati bersama oleh semua warga sekolah.

Adapun Program kewirausahaan yang dikembangkan tersebut disesuaikan dengan ruang lingkup materi pembelajaran yang terkait dengan nilai-nilai kewirausahaan yang disepakati untuk dilaksanakan oleh warga sekolah. Hal ini dilakukan agar program tersebut selaras dengan materi dan tuntutan kompetensi pada setiap mata pelajaran. Adapun Mata pelajaran yang telah diintegrasikan dengan program kewirausahan tersebut diantaranya adalah mata pelajaran ekonomi, Biologi, Kimia, Fisika dan seni budaya dan prakarya.

Bertolak dari pemikiran tersebut maka penulis mengangkat pengalaman terbaik (best practice) dalam makalah ini yang berjudul "Implementasi program pendidikan kewirausahaanmelalui penerapan proses pembelajarandalam Mewujudkan kreativitas dan inovasi Peserta Didik SMA Negeri 2 Pekanbaru”.

\section{Profesionalisme Guru}

Guru Profesional adalah guru yang memiliki komponen tertentu sesuai dengan persyaratan yang dituntut oleh profesi keguruan. Guru profesional senantiasa menguasai bahan atau materi pelajaran yang akan diajarkan dalam interaksi belajar mengajar, serta senantiasa mengembangkan kemampuan secara berkelanjutan, baik dalam segi ilmu yang dimilikinya maupun pengalamannya. Sedangkan Profesionalisme guru adalah kemampuan guru untuk melakukan tugas pokoknya sebagai pendidik dan pengajar meliputi kemampuan merencanakan, melakukan, dan melaksanakan evaluasi pembelajaran.

Guru profesional hendaknya memiliki empat kompetensi guru yang telah ditetapkan dalam Undang-undang Republik Indonesia Nomor 14 Tahun 2005 Tentang Guru dan Dosen yaitu, kompetensi pedagogik, kepribadian, profesional dan sosial. Oleh karena itu, selain terampil mengajar, seorang guru juga memiliki pengetahuan yang luas, bijak, dan dapat bersosialisasi dengan baik. Tentunya untuk menjadi guru yang profesional harus memenuhi kriteria kriteria diantaranya;

1. Mempunyai akhlak dan budi pekerti yang luhur sehingga mampu memberikan contoh yang baik pada anak didik.

2. Mempunyai kemampuan untuk 
mendidik dan mengajar anak didik dengan baik.

3. Menguasai bahan atau materi pelajaran yang akan diajarkan dalam interaksi belajar mengajar

4. Memiliki kualifikasi akademik dan latar belakang pendidikan sesuai bidang tugas.

5. Menguasai berbagai adminitrasi kependidikan ( RPP, Silabus, Kurikulum, KKM, dan sebagainya )

6. Mempunyai semangat dan motivasi yang tinggi untuk mengabdikan ilmu yang dimiliki pada peserta didik.

7. Tidak pernah berhenti untuk belajar dan mengembangkan kemampuannya.

8. Mengikuti diklat dan pelatihan untuk menambah wawasan dan pengalaman.

9. Aktif, kreatif, dan inovatif untuk mengembangkan pembelajaran dan selalu up to date terhadap informasi atau masalah yang terjadi di sekitar.

10. Menguasai IPTEK (komputer, internet, blog, facebook, website, dsb).

11. Gemar membaca sebagai upaya untuk menggali dan menambah wawasan.

12. Tidak pernah berhenti untuk berkarya (membuat PTK, bahan ajar, artikel, dsb)

13. Mampu berinteraksi dan bersosialisasi dengan orangtua murid, teman sejawat dan lingkungan sekitar dengan baik.

14. Aktif dalam kegiatan-kegiatan organisasi kependidikan (KKG, PGRI, Pramuka)

15. Mempunyai sikap cinta kasih, tulus dan ikhlas dalam mengajar

\section{Kewirausahaan}

Kewirausahaan

(entrepreneurship) adalah suatu disiplin ilmu yang mempelajari tentang nilai, kemampuan, dan perilaku seseorang dalam menghadapi tantangan hidup dan cara memperoleh peluang dengan berbagai resiko yang mungkin dihadapinya. Oleh karena kewirausahaan merupakan suatu disiplin ilmu tersendiri, yang memiliki proses yang sistematis, dan dapat diterapkan dalam bentuk penerapan kreatifitas dan keinovasian maka SMA Negeri 2 Pekanbaru mengintegrasikan dengan mata pelajaran yang relevan dan menjadi salah satu program keunggulan di SMA Negeri 2 Pekanbaru.

Kewirausahaan/entrepreneurship adalah suatu disiplin ilmu yang mempelajari tentang nilai, kemampuan, dan perilaku seseorang dalam menghadapi tantangan hidup dan cara memperoleh peluang dengan berbagai resiko yang mungkin dihadapinya. Oleh karena kewirausahaan merupakan suatu disiplin ilmu tersendiri, yang memiliki proses yang sistematis, dan dapat diterapkan dalam bentuk penerapan kreatifitas dan keinovasian maka SMA Negeri 2 Pekanbaru mengintegrasikan dengan mata pelajaran yang relevan dan menjadi salah satu program keunggulan di SMA Negeri 2 Pekanbaru.

Penulis sebagai pengemban amanah dari Dinas Pendidikan Provinsi Riau menjadi kepala sekolah SMA Negeri 2 Pekanbaru memiliki tujuan dan pengharapan yang dijabarkan pada visi misi dan tujuan sekolah serta membuat rencana strategis yang realistik terhadap pengembangan sekolah yang kompetitif dalam menghadapi tantangan abad 21 dengan mengimplentasikan program kewirausahaan menjadi salah satu program unggulan yang realistik dan diintegrasikan pada mata pelajaran yang relevan. Realistik artinya tujuan disesuaikan dengan sumber daya pendukung yang dimiliki. Semakin jelas tujuan yang ditetapkan semakin besar peluang untuk meraihnya dan terukur dalam mengembangkan sekolah.

\section{Perubahan Pelaksanaan Pembelajaran Kewirausahaan dari Teori ke Praktik}

Dengan cara ini, pembelajaran kewirausahaan diarahkan pada pencapaian 
tiga kompetansi yang meliputi penanaman karakter wirausaha, pemahaman konsep dan skill, dengan bobot yang lebih besar pada pencapaian kompetensi jiwa dan skill dibandingkan dengan pemahaman konsep. Dalam struktur kurikulum SMA, pada mata pelajaran ekonomi ada beberapa Kompetensi Dasar yang terkait langsung dengan pengembangan pendidikan kewirausahaan. Mata pelajaran tersebut merupakan mata pelajaran yang secara langsung (eksplisit) mengenalkan nilainilai kewirausahaan, dan sampai taraf tertentu menjadikan peserta didik peduli dan menginternalisasi nilai-nilai tersebut. Salah satu contoh model pembelajaran kewirausahaan yang mampu menumbuhkan karakter dan perilaku wirausaha dapat dilakukan dengan cara mendirikan kantin jujur, dsb.

\section{Metode Penelitian}

Penelitian ini merupakan penelitian kebijakan. Penelitian dilakukan untuk mengungkapkan dampak ari kebijakan yang dibuat pimpinan suatu organisasi atau institusi. Analisis data yang digunakan dalam penelitian ini berupa analisis deskriptif yang menjabarkankebijakan beserta dampak yangditimbulkan dari kebijakan tersebut.

\section{Hasil Penelitian}

\section{Hasil atau Dampak yang dicapai}

Pengelolaan Program Kewirausahaan Pengelolaan kewirausahaan dilakukan melalui berbagai kegiatan baik dikelas, disekolah, maupun dimasyarakat :

\section{1). Pengelolaan di Kelas}

Pengelolaan di kelas di lakukan melalui proses belajar mengajar pada mata pelajaran Kimia, Fisika, Biologi, Ekonomi dan Seni Budaya. Dimana pendidikan kewirausahaan ini dirancang sedemikian rupa dalam mengembangkan pendidikan kewirausahaan. Oleh karena itu tidak selalu diperlukan kegiatan belajar mengajar (KBM) khususnya untuk mengembangkan nilai-nilai kewirausahaan. Pengembangan nilai-nilai kewirausahaan memerlukan upaya pengkondisikan sehingga peserta didik memiliki kesempatan untuk memunculkan perilaku yang menunjukkan nilai-nilai kewirausahaan itu.

\section{2). Pengelolaan di Sekolah}

Pengelolaan yang dilakukan disekolah dilakukan dalam bentuk kegiatan sekolah yang diikuti oleh seluruh peserta didik, tenaga pendidik, dan tenaga kependidikan SMA Negeri 2 Pekanbaru. Program kewirausahaan dirancang sejak awal tahun pelajaran, dituangkan pada kalender akademik dan dilakukan sehari-hari sebagai sebagaian dari budaya sekolah. Adapun kegiatan yang dapat dilakukan / dimasukkan ke dalam program sekolah dalah membuat berbagai macam produk "Prakarya" yang telah dihasilkan oleh peserta didik, pameran hasil karya peserta didik, melalukan wawancara kepada tokoh wirausaha, mengundang narasumber untuk berdiskusi, berceramah yang berhubungan dengan kewirausahaan, serta pengembangan nilai-nilai kewausahaan pada kegiatan kesiswaan. Pendidikan kewirausahaan juga bisa dilaksanakan melalui kegiatan ekstrakulikuler dengan cara melatih jiwa kewirausahaan peserta didik melalui kegiatan maupun dengan mengembangkan usaha yang terkait dengan bakat dan minat peserta didik. Peran guru adalah menggali potensi dan cita-cita peserta didik secara jelas sehingga dapat menginspirasi setiap peserta didik untuk dapat melihat jika kewirausahaan dalam dirinya.

\section{3). Pengelolaan di Masyarakat}

Pengelolaan kewirausahaan di masyarakat dilakukan melalui berbagai kegiatan yang diikuti oleh seluruh peserta didik yang dirancang sekolah sejak awal tahun pelajaran dan dimasukkan kedalam kalender akademik. Adapun pengelolaan yang ada di masyarakat adalah kunjungan ke tempat-tempat yang dapat menumbuhkan semangat berwirausaha. Adapun produk unit usaha yang telah dikembangkan di SMA Negeri 2 Pekanbaru diantaranya adalah Budi Daya 
Ikan Lele, Budi daya Tanaman (Jahe Merah, Kol, Lidah Buaya), Pengelolaan Makanan dan Minuman serta Kerajinan (Rajutan, Bunga Kristal, Souvenir, Anyaman Rotan).

\section{Kegiatan Pameran dan bazar diakhir tahun}

Program ini dilakukan oleh peserta didik dalam rangka mempelajari aspek pemasaran dalam berwirausaha. Kegiatan ini dapat dilakukan di sekolah sesuai dengan program yang telah direncanakan. Hal-hal yang perlu diketahui peserta didik saat melaksanakan pameran/bazar adalah seni menjual, harga jual, kepuasan pelanggan, promosi, negosiasi, serta saluran dan jaringan distribusi. Beberapa hal yang perlu diketahui peserta didik pada saat kegiatan pameran/bazar adalah :

a. Memahami Seni Menjual

Menjual berhubungan langsung dengan kebutuhan dan keluhan pelanggan, pasar, perubahan, persaingan dan peluang. Oleh karena itu penjual mempunyai informasi paling awal dan penting untuk dijadikan cikal bakal sebuah bisnis.

b. Menetapkan Harga Jual

Untuk menetapkan harga jual harus disesuaikan dengan target pasar, segmen pasar, dan posisi produk pasar. Penentuan harga jual produk dapat ditentukan dengan tiga cara, yaitu :

- Harga jual ditetapkan berdasarkan harga pasar (market based price)

Harga ini ditentukan oleh aspek persaingan antar produk yang akan ditawarkan pada konsumen, dengan harga produk dari pesaing yang sudah ada di pasar.

- Harga jual ditetapkan berdasarkan biaya (cost based price)

Prinsip penentuan harga berdasarkan biaya produksi ditambah laba yang ditentukan akan mempunyai resiko, yaitu harga yang ditawarkan bisa lebih tinggi dari harga produk pesaing.

- Harga jual ditetapkan berdasarkan titik impasnya (break even point based price)

Penentuan harga jual produk berdasarkan pada berapa kapasitas yang diproduksi dimana biaya bisa ditutup oleh harga jual dikalikan dengan total produksi tanpa profit. Sehingga diperlukan berapa biaya per unit, biaya overhead per unit dan biaya tenaga kerja per unit.

Kegiatan pemeran dan bazar kewirausahaan SMA Negeri 2 Pekanbaru dilaksanakan pada saat kegiatan diakhir semester ganjil sebelum siswa menerima rapor. Kegiatan pameran dan Bazar inidihadiri oleh undangan dari berbagai pihak terkait termasuk orang tua siswa SMA Negeri 2 Pekanbaru. Acara tersebut secara resmi di buka oleh Kepala Dinas Pendidikan Provinsi Riau dan dihadiri oleh Kepala Dinas Pendidikan Kota Pekanbaru dan instansi terkait.

Pengembangan Program kewirausahaan merupakan program keunggulan yang di implementasikan dalam pelaksanaan kegiatan sekolah dan layanan pendidikan bermuatan nilai-nilai dan jiwa kewirausahaan. Dengan pengembangan program kewirausahaan penulis sebagai kepala sekolah lebih proaktif dalam mencari dan memanfaatkan peluang untuk mencapai kesuksesan sehingga akan membawa perubahan dalam organisasi ke arah yang lebih adaptif dalam menghadapi berbagai perubahan lingkungan dan tantangan abad 21.

$$
\text { Pengembangan }
$$

Program

kewirausahaan di SMA Negeri 2 Pekanbaru adalah mempunyai bertujuan untuk mengantisipasi berbagai perubahan dengan visi masa depan yang jelas serta berupaya mendorong suatu kerja sama dalam melakukan perubahan melalui fleksibilitas menjalankan perannya dalam mengelola organisasi.

Program kewirausahaan yang dirancang dan disusun oleh SMA Negeri 2 
Pekanbaru telah sepakati oleh seluruh warga SMA Negeri 2 Pekanbaru sesuai dengan kalender akademik dan telah disepakati serta dikembangkan disesuaikan dengan ruang lingkup materi dan pembelajaran yang terkait dengan nilainilai kewirausahaan. Hal ini dilakukan agar program tersebut selaras dengan materi dan tuntutan kompetensi pada setiap mata pelajaran yang diintegrasikan dengan program kewirausahaan. Adapaun mata pelajaran yang telah diintegrasikan seperti mata pelajaran Kimia, Fisika, Biologi, Ekonomi dan Seni Budaya.

Program ini dilaksanakan dalam rangka mengembangkan kompetensi peserta didik saat proses kegiatan belajar mengajar (KBM) di unit usaha/produksi adalah mempelajari standar mutu, kegunaan mutu, bagaimana standar dan produksi mutu dalam membuat produk yang bermutu dengan cara :

a. Berkoordinasi dengan pengelola unit/produksi sebelum pratek dilapangan

b. Mengetahui proses produksi, proses pencarian bahan baku, sistem mutu, dan proses pemasarannya.

c. Belajar mengenai alat-alat dengan mempelajari jenis, spesifikasi dan kapasitas alat-alat yang digunakan.

d. Mengenal konsumen, pasar dan alasan mengapa sebuah produk berhasil atau gagal dipasarkan.

Kegiatan pemeran dan bazar kewirausahaan SMA Negeri 2 Pekanbaru ini secara resmi di buka oleh Kepala Dinas Pendidikan Provinsi Riau dan dihadiri oleh Kepala Dinas Pendidikan Kota Pekanbaru serta undangan dari berbagai pihak terkait. Dengan demikian Guru sebagai agent of change yang berada pada garda paling depan secara langsung berhadapan dengan peserta didik dalam kegiatan pembelajaran dapat memberikan ilmu yang bermanfaat serta mampu menanamkan nilai-nilai dan jiwa kewirausahaan pada peserta didik dalam menghadapi tantangan abad 21.

\section{KESIMPULAN}

$\begin{array}{cc}\text { Pengembangan } & \text { Program } \\ \text { kewirausahaan merupakan } & \text { program }\end{array}$ keunggulan yang di implementasikan dalam pelaksanaan kegiatan sekolah dan layanan pendidikan bermuatan nilai-nilai dan jiwa kewirausahaan. Dengan pengembangan program kewirausahaan penulis sebagai kepala sekolah lebih proaktif dalam mencari dan memanfaatkan peluang untuk mencapai kesuksesan sehingga akan membawa perubahan dalam organisasi ke arah yang lebih adaptif dalam menghadapi berbagai perubahan lingkungan dan tantangan abad 21 .

Pengembangan Program kewirausahaan di SMA Negeri 2 Pekanbaru adalah mempunyai bertujuan untuk mengantisipasi berbagai perubahan dengan visi masa depan yang jelas serta berupaya mendorong suatu kerja sama dalam melakukan perubahan melalui fleksibilitas menjalankan perannya dalam mengelola organisasi. Dengan mengimplementasikan program kewirausahaan dalam proses pembelajaran akan memberi pengaruh yang positif terhadap anggota organisasi yang berdampak pada kinerja mereka.

Program kewirausahaan yang dirancang dan disusun oleh SMA Negeri 2 Pekanbaru telah sepakati oleh seluruh warga SMA Negeri 2 Pekanbaru sesuai dengan kalender akademik dan telah disepakati serta dikembangkan disesuaikan dengan ruang lingkup materi dan pembelajaran yang terkait dengan nilainilai kewirausahaan. Hal ini dilakukan agar program tersebut selaras dengan materi dan tuntutan kompetensi pada setiap mata pelajaran yang diintegrasikan dengan program kewirausahaan. Adapaun mata pelajaran yang telah diintegrasikan seperti mata pelajaran Kimia, Fisika, Biologi, Ekonomi dan Seni Budaya.

Program ini dilaksanakan dalam rangka mengembangkan kompetensi peserta didik saat proses kegiatan belajar mengajar (KBM) di unit usaha/produksi adalah mempelajari standar mutu, kegunaan mutu, bagaimana standar dan 
produksi mutu dalam membuat produk yang bermutu dengan cara :
e. Berkoordinasi dengan pengelola unit/produksi sebelum pratek dilapangan

f. Mengetahui proses produksi, proses pencarian bahan baku, sistem mutu, dan proses pemasarannya.

g. Belajar mengenai alat-alat dengan mempelajari jenis, spesifikasi dan kapasitas alat-alat yang digunakan.

h. Mengenal konsumen, pasar dan alasan mengapa sebuah produk berhasil atau gagal dipasarkan.

Dengan mencoba dan ikut dalam kegiatan unit usaha/produksi diharapkan akan dapat menambah :

a. Wawasan peserta didik tentang kewirausahaan.

b. Pengetahuan tentang kewirausahaan, baik dalam teori maupun praktik.

c. Pengalaman peserta didik, bukan hanya belajar di kelas tetapi juga belajar di dunia nyata

d. Hasrat untuk menjadi wirausaha menjadi tinggi.

Pameran / Bazar adalah Program yang dilakukan oleh peserta didik dalam rangka mempelajari aspek pemasaran dalam berwirausaha. Kegiatan ini dapat dilakukan di sekolah sesuai dengan program yang telah direncanakan. Hal-hal yang perlu diketahui peserta didik saat melaksanakan pameran/bazar adalah seni menjual, harga jual, kepuasan pelanggan, promosi, negosiasi, serta saluran dan jaringan distribusi. Beberapa hal yang perlu diketahui peserta didik pada saat kegiatan pameran/bazar adalah :

c. Memahami Seni Menjual

Menjual berhubungan langsung dengan kebutuhan dan keluhan pelanggan, pasar, perubahan, persaingan dan peluang. Oleh karena itu penjual mempunyai informasi paling awal dan penting untuk dijadikan cikal bakal sebuah bisnis.

d. Mentapkan Harga Jual

Untuk menetapkan harga jual harus disesuaikan dengan target pasar, segmen pasar, dan posisi produk pasar. Penentuan harga jual produk dapat ditentukan dengan tiga cara, yaitu :

- Harga berdasarkan harga pasar (market based price)

Harga ini ditentukan oleh aspek persaingan antar produk yang akan ditawarkan pada konsumen, dengan harga produk dari pesaing yang sudah ada di pasar.

- Harga berdasarkan biaya (cost based price)

Prinsip penentuan harga berdasarkan biaya produksi ditambah laba yang ditentukan akan mempunyai resiko, yaitu harga yang ditawarkan bisa lebih tinggi dari harga produk pesaing.

- Harga berdasarkan titik impasnya (break even point based price)

Penentuan harga jual produk berdasarkan pada berapa kapasitas yang diproduksi dimana biaya bisa ditutup oleh harga jual dikalikan dengan total produksi tanpa profit. Sehingga diperlukan berapa biaya per unit, biaya overhead per unit dan biaya tenaga kerja per unit.

Kegiatan pemeran dan bazar kewirausahaan SMA Negeri 2 Pekanbaru ini secara resmi di buka oleh Kepala Dinas Pendidikan Provinsi Riau dan dihadiri oleh Kepala Dinas Pendidikan Kota Pekanbaru serta undangan dari berbagai pihak terkait. Dengan demikian Guru sebagai agent of change yang berada pada garda paling depan secara langsung berhadapan dengan peserta didik dalam kegiatan pembelajaran dapat memberikan ilmu yang bermanfaat serta mampu menanamkan nilai-nilai dan jiwa kewirausahaan pada peserta didik dalam menghadapi tantangan abad 21 ..

\section{SARAN}

1. Kepala Sekolah sebagai teman sejawat Semua Kepala Sekolah Menegah Atas (SMA) dapat mengimplementasikan program pengembangan kewirausahaan dalam kegiatan nyata disekolah yang dipimpinnya sehingga 
lulusan yang dihasilkan mampu menciptakan lapangan kerja sendiri dengan berwirausaha.

2. Guru dapat mempersiapkan perangkat pembelajaran dengan mengintegrasi program kewirausahaan pada siswa melalui proses pembelajaran sesuai dengan mata pelajaran yang diampunya

3. Dinas Pendidikan perlu melakukan pengkajian yang lebih mendalam tentang Pendidikan kewirausahaan yang dapat dikembangkan oleh sekolah secara efektif dan dapat diterapkan pada Sekolah Menengah Atas.

\section{DAFTAR PUSTAKA}

Ahmad Sanusi. 2015. Menelaah Potensi Untuk Membina Program Kewirausahan dan Mengantar Perirausaha Muda. Bandung. UPI.

Barth, Peter. 2012. Enterpreneuship and Economic Development. The Free Press New York Colier-Mc. Milan Ltd.

Direktorat pembinaan Sekolah Menengah Atas. 2016. Konsep dan Strategi Program Kerirausahaan SMA. Jakarta.

Eddy Soeryanto. 2007. Enterpreneurship Menjadi Pebisnis Ulung. Jakarta. PT. Elex Media Komutindu Kompas Gramedia.

Joko Untoro. 2014. Buku Pintar Pelajaran. Jakarta. Wahyu Media.

Noor Jamaludin. 2012. Definisi Tentang Guru. Bandung. Sinar Baru Algesindu.

Siswanto Sudomo. 2016. Perangkat dan Tekhnik Analisis Investasi di Pasar Modal Indonesia. Bandung. PT. Bima

Suryana. 2013. Kewirausahaan Pedoman Praktis : Kiat dan Proses Menuju Sukses Edisi Ketiga. Jakarta. Salemba.

Tati Suhartati. 2012. Teori Ekonomi Mikro. Jakarta. Salemba Empat

Winarno. 2009. Kewirausahaan dan
Management Usaha Kecil. Salemba Empat. Jakarta. 
ISSN $1411-3570$

eISSN 2579-9525 